\section{Etiolation Improves Rooting of Bigtooth Maple Cuttings}

\author{
Melody Reed Richards ${ }^{1,3}$ and Larry A. Rupp ${ }^{2,4}$
}

AdDitional INDEX WORDs. Aceraceae, propagation, cutting, nursery, landscape, Acer grandidentatum

SUMMARY. Bigtooth maple (Acer grandidentatum) has potential as a small, water conserving landscape tree in western landscapes. This potential has been hindered in part by the difficulty in asexually propagating superior accessions. The ability of etiolation to enhance rooting of softwood cuttings of selected wild accessions was determined by grafting six accessions onto seedling rootstocks to use as stock plants. Etiolation was applied to stock plants by placing open-ended, black, velour, drawstring bags over the end of pruned shoots at bud swell allowing new shoots to develop and grow out the end of the bag while leaving the base of the shoot covered. In 2009 and 2010, cuttings from etiolated and nonetiolated shoots were treated with 4000 ppm indole-3-butyric acid (IBA) +2000 ppm naphthaleneacetic acid (NAA), stuck in a premoistened 3 perlite: 1 peat (by volume) rooting substrate and placed under intermittent mist. After 4 weeks, 89\% (2009) and 85\% (2010) of the etiolated cuttings rooted and only 47\% (2009) and 17\% (2010) of the nonetiolated cuttings rooted. Etiolated cuttings produced on average $11.3(2009)$ and 7.2 (2010) roots per cutting and nonetiolated 2.1 (2009) and $0.5(2010)$ roots per cutting. Etiolation, and its application through the use of black cloth bags, can be an effective way to increase the rooting of bigtooth maple cuttings and the availability of these plants for use in water conserving landscaping.

$\mathrm{B}$ igtooth or canyon maple is a small tree native to the intermountain western United States and possesses characteristics valued by the nursery and landscape industries (Barker, 1974; Kuhns, 2003; Tankersley and Emino, 1980), including a deciduous habit (Eastmond, 1968), adaptability to a wide range of temperatures $\left(-30\right.$ to $\left.100{ }^{\circ} \mathrm{F}\right)$ (Kuhns, 2003), drought tolerance (15-20 inches of annual precipitation), and adaptability to a wide range of soils and habitats. It produces a winged-samara and has leaves with deep, simple,

Plants, Soils, and Climate Department, Utah State University, 4820 Old Main Hill, Logan, UT 84322

This paper is a portion of a thesis submitted by Melody Richards in fulfilling a Masters Degree.

This project was supported in part by the Utah Agricultural Experiment Station, the Center for Water Efficient Landscaping, the J. Frank Schmidt Family Charitable Foundation, the Drought Management Utah project (USDA-CREES UT award 2008-3455219042), and a Utah Department of Agriculture and Food Specialty Crop Block Grant.

We thank Xin Dai for statistical advice.

Mention of a trademark, proprietary product, or vendor does not constitute a guarantee or warranty of the product by the Utah State University and does not imply its approval to the exclusion of other products or vendors that also may be suitable.

${ }^{1}$ Former graduate student

${ }^{2}$ Professor

${ }^{3}$ Current address: 53 Kimberly Drive, Council Bluffs, IA 51503 .

${ }^{4}$ Corresponding author. E-mail: Larry.Rupp@usu.edu. tooth-like lobes. The fall foliage ranges in color from yellow to orange to red while samaras can be green to red. Bigtooth maple exhibits a wide variety of tree forms (including columnar, native habitat, it exhibits an even more remarkable range from single stem trees to short, multistemmed shrubs.

Bigtooth maple is uncommon in both the nursery trade and in urban landscapes, with Rocky Mountain Glow ${ }^{\circledR}$ ('Schmidt') being the primary cultivar and the cultivars Manzano ${ }^{\mathrm{TM}}$ and Western Torch Wasatch Maple having limited availability. Propagation of cultivars is primarily done by budding on sugar maple (Acer saccharum) rootstocks. While these budded plants have been successfully grown in Utah, there is some concern in the industry that sugar pyramidal, and oval). Moreover, in its maple rootstocks are not the best option for Utah soils because of the potential for iron chlorosis with alkaline soils. Bigtooth maple is easily and commonly grown from seed for reclamation, but the genetic diversity in color, size, and especially growth habit make it difficult to market seedling plants as performing within known parameters. With the exception of budding, vegetative propagation has been so difficult as to be commercially unfeasible (Donnelly and Yawney, 1972; Tankersley, 1981). If asexual propagation were easier to accomplish, it is reasonable to expect that superior specimens would be more readily available to the landscape industry and would provide utility in landscaping.

Past efforts in asexual propagation of bigtooth maple have resulted in limited success. Bigtooth maple propagates itself naturally by layering when lower branches come in contact with the soil and form roots (Christensen, 1962). Tankersley (1981) observed rooting on $20 \%$ of mound layered and $71 \%$ of trench layered 1-yearold maple seedlings. Although trench layering had a higher rooting percentage, it is a very labor intensive propagation technique. Micropropagation of bigtooth maple resulted in $15 \%$ rooting (Bowen-O'Connor et al., 2007) of juvenile material, but has not been shown effective in propagating mature specimens. Asexual propagation by cuttings has been even less successful with Tankersley achieving only $0.8 \%$ rooting (1981). If this plant is to be used as a landscape ornamental, methods of asexual propagation must be improved to meet the needs of the nursery and landscape industries (Bowen-O'Connor et al., 2007).

A review of past research on stem cuttings reveals that juvenility, auxins, girdling, wounding, tissue carbohydrate levels, hedging, selection of 
cutting material, etiolation, and/or other factors can improve rooting in hard-to-root woody species (Griffin and Bassuk, 1996; Hartmann et al., 2011; Herman and Hess, 1963; Maynard and Bassuk, 1987). It has long been known that etiolation enhances root formation and relatively recent research has shown that etiolation and banding techniques can dramatically improve rooting of many woody plants (Maynard and Bassuk, 1987). Adventitious root formation and uniformity are also increased in hard-to-root cuttings when wounded and treated with an auxin, such as IBA (Alsup et al., 2003; Griffin and Bassuk, 1996).

Propagation via cuttings is a cheap, simple, and effective method that will allow propagators to produce commercial quantities of selected specimens if it can be effective with bigtooth maple (Griffin and Bassuk, 1996). Our objective was to determine if etiolation would improve a cutting propagation system using coppiced stock plants, wounding, supplemental auxin, bottom heat, shading, and intermittent mist to increase rooting of bigtooth maple cuttings to economically acceptable levels.

\section{Materials and methods}

Multiple accessions (five in 2009 and six in 2010) of bigtooth maple were evaluated for propagation efficiency using softwood cuttings. The accessions (USU-ACGR-1001, USUACGR-1002, USU-ACGR-1003, USUACGR-1004, USU-ACGR-1005, and USU-ACGR-1009) were previously selected from wild populations in northern Utah in an area ranging from latitudes $41.520^{\circ} \mathrm{N}$ to $41.875^{\circ} \mathrm{N}$ and longitudes $111.750^{\circ} \mathrm{W}$ to $111.943^{\circ} \mathrm{W}$ at elevations of $5250-5900 \mathrm{ft}$ and originally grafted onto seedling rootstocks established in 1999 in a coppiced, stoolbed environment (Utah State University Greenville Research Farm, Millville silt loam soil). Grafted plants were heavily pruned annually and in general kept to less than $6 \mathrm{ft}$ tall after pruning. Experiments were initiated in late January and early February by making pruning cuts immediately basipetal to the third bud from the base (disregarding any bud less than $1 / 2$ inch from bottom) of previous season's shoots, leaving a 2 - to 5 -inch stub above the most acropetal remaining bud.
Etiolation was induced by placing open-ended, black, $8 \times 18-\mathrm{cm}$, velour, drawstring bags (SoftPouch, Amherst, NY) over the terminals of pruned shoots. The drawstring was tied just below the uppermost buds. The stub left above the bud supported the bag and prevented it from folding over and inhibiting shoot elongation. Bags were placed over the pruned shoots at incipient bud swell on three different dates in 2009 (22 and 28 Apr., and 2 May), and on four different dates in 2010 (20 Apr., 21 Apr., 26 Apr., and 8 May) depending on the accession. As a result, budbreak and shoot development occurred in the low light $\left[\approx 5 \mu \mathrm{mol} \cdot \mathrm{m}^{-2} \cdot \mathrm{s}^{-1}\right.$ photosynthetic photon flux $(P P F)$ as measured independently] inside the bag environment. With time, the shoots emerged from the bag with the tips acclimating to full sun, while the etiolated base of the shoot remained covered by the bag (Fig. 1). Pruned shoots were randomly assigned to either etiolated or nonetiolated (control) treatments.

Softwood cuttings were selected when $\approx$ two sets of fully expanded leaves emerged from the top of the bag (in late May to early June after $\approx 3$ to 4 weeks of shoot elongation) and when the total shoot length of nonetiolated shoots averaged 20 to $25 \mathrm{~cm}$. Cuttings were taken on three different dates in 2009 (21 May, 22 May, and 28 May) and on four different dates in 2010 (24 May, 31 May, 2 June, and 7 June). Etiolated and control shoots were harvested between 0600 to 0800 HR by cutting the shoots just above the most basipetal node (which was also the node just below the drawstring of the bag where etiolated). Cut shoots were immediately placed in sealed 2.5 -gal plastic freezer bags in an ice-filled cooler until stored in a refrigerator $\left(4^{\circ} \mathrm{C}\right)$.

Shoots were removed from refrigeration within $1-2 \mathrm{~h}$ and held in a cooler until randomly selected for sticking. In general, each shoot potentially had two cuttings because of the opposite phylotaxis of maples, and the healthier, more vigorous cutting was selected. Where two equally healthy cuttings existed, one was randomly selected for propagation. Cuttings were made by making the bottom cut immediately above any latent buds at the shoot base and the upper

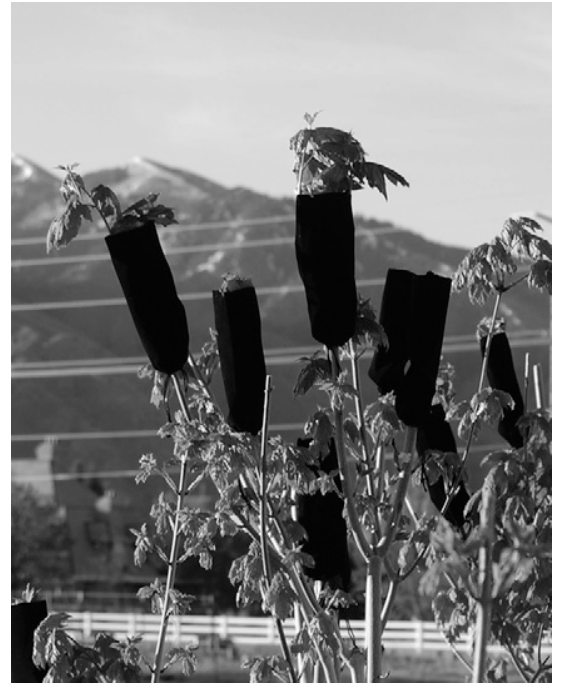

Fig. 1. Etiolation of bigtooth maple shoots. Black, velour bags were placed over the most distal bud at bud swell to promote etiolation. The bags were open at the top to allow shoots to grow outward. Softwood cuttings were collected when $\approx$ two sets of fully expanded leaves had emerged from the top of the bag and the average length of nonetiolated shoots was 20 to $25 \mathrm{~cm}$ (7.9 to 9.8 inches) (after $24-42 \mathrm{~d}$ depending on year and accession).

cut just above the second node with leaves, resulting in two sets of leaves on each cutting. Measurements included parent shoot length, cutting length and diameter, leaf damage, and leaves per cutting. Cuttings deemed unable to root because of small size or damage were excluded from the experiments and rooting calculations.

Cuttings were wounded on two sides (2009) or one (2010) by scraping $\mathrm{l} \mathrm{cm}$ of the bark down to the woody tissue with a knife held perpendicular to the stem. Knives were sanitized with $70 \%$ ethyl alcohol between each cutting. The cuttings were dipped in $4000 \mathrm{ppm} \mathrm{IBA}+2000 \mathrm{ppm}$ NAA [prepared as $20 \mathrm{~mL}$ Dip ' $\mathrm{N}$ Grow ${ }^{\circledR}$ (Dip 'N Grow, Clackamas, OR) diluted with $30 \mathrm{~mL}$ of $50 \%$ ethyl alcohol] for $5 \mathrm{~s}$ and shaken once to remove the excess.

Cuttings were stuck $\approx 2$ to $5 \mathrm{~cm}$ deep in every other cell of a 606 tray $(2.5 \times 2.5 \times 3.0$-inch cells $)$ in premoistened media ( 3 perlite: 1 peat by volume) and misted with deionized water using a spray bottle to keep the cuttings hydrated before placing them on a mist bench.

The greenhouse was shaded with liquid shade (Kool Ray ${ }^{\mathrm{TM}}$; Continental 
Products Co., Euclid, OH) in 2009. The cuttings were also placed under a double-folded spunbonded polyester sheet, which resulted in 350 to $470 \mu \mathrm{mol} \cdot \mathrm{m}^{-2} \cdot \mathrm{s}^{-1} \mathrm{PPF}$. The polyester sheet reduced air movement from cooling fans and decreased light levels. The greenhouse was covered with black, plastic shadecloth at $60 \%$ shading in 2010 to improve consistency in shading, which resulted in similar light levels of $\approx 470 \mu \mathrm{mol} \cdot \mathrm{m}^{-2} \cdot \mathrm{s}^{-1}$ $P P F$. In 2010, one layer of the polyester sheet was used instead of two, and only on the sides of the bench to reduce excessive air movement across the cuttings.

Cuttings were placed on heating mats with the temperature set at 25$26{ }^{\circ} \mathrm{C}$, but with actual bottom heat ranging from 20 to $30{ }^{\circ} \mathrm{C}$. Misting was done with reverse osmosis treated water. The mist was applied at $7 \mathrm{~s}$ every $12 \mathrm{~min}$ from 0600 to $2100 \mathrm{HR}$. The greenhouse day/night temperatures were set at $65 / 60^{\circ} \mathrm{F}$ (day/night), but ranged from 66 to $75^{\circ} \mathrm{F}$ throughout the day.

Gray mold (Botrytis sp.) was prevented by applying weekly applications of thiophanate methyl (Cleary 3336F®; Cleary Chemical Co., Dayton, $\mathrm{NJ})$ at $0.41 \mathrm{~mL} \cdot \mathrm{L}^{-1}$ at night following cessation of misting. Phytophthora root rot (Phytophthora sp.) was prevented by a applying a one-time drench of mefenoxam (Mefenoxam 2AQ; FarmSaver.com, Raleigh, NC) at a rate of $0.135 \mathrm{~mL} / \mathrm{gal}(17 \mathrm{~mL}$ solution per cell) after sticking. Cutting flat positions on the bench were randomly rotated every other day and any dead or diseased leaves were removed to reduce potential sources of inocula.

Rooting response was evaluated after 4 weeks by washing media from the cutting, and determining the presence or absence of callus, root number per cutting, and leaf number per cutting. A root was defined as anything longer than it was wide (usually $\approx 1 \mathrm{~mm}$ ). Evaluation of roots in 2009 was done nondestructively. In 2010, root evaluation was conducted in a destructive manner by removing all roots to insure greater accuracy.

Data were analyzed with the statistical programs Statistix 9 (Analytical Software, Tallahassee, FL) and SAS (version 9.2; SAS Institute, Cary, NC), as follows: The effect of etiolation on percentage of rooted cuttings was determined by completing a square root transformation of percentages to better fit the $t$ test normality assumption and doing a two-sample $t$ test with the Satterthwaite (1946) method because of unequal variances. The effect of etiolation on the number of roots was determined by first completing a $\log$ transformation of root number data to fit the normality assumption and then an analysis of variance (ANOVA).

To determine the effect of tree accessions on percentage of rooted cuttings and number of roots (mean of all cuttings), a MIXED Procedure was completed using SAS to find the significant differences of least square means. The effect of etiolation on leaf damage was determined via a chisquare test for heterogeneity or independence, and an ANOVA was used to determine the effects of etiolation on the number of leaves lost. Leaf damage was determined by observation when the cuttings were stuck, while the number of leaves lost was observed during rooting. A chi-square test of heterogeneity or independence was also performed to determine the effect of etiolation on callus formation.

\section{Results}

In $2009,89 \%$ of all etiolated cuttings rooted, compared with $47 \%$ of the nonetiolated ( $P=0.0004$; Fig. $2 \mathrm{~A})$. Within accessions, etiolated cuttings of USU-ACGR-1001, USU-ACGR1002, USU-ACGR-1004, and USUACGR-1005 all had over 83\% rooting. Among etiolated treatments, rooting did not differ among accessions, except between USU-ACGR-1005 and USUACGR-1003, with $100 \%$ and $71 \%$, respectively. Rooting of nonetiolated cuttings was more variable between accessions and ranged from $18 \%$ to $67 \%$. Etiolated cuttings had an average of $85 \%$ rooting success overall in 2010 , whereas only $17 \%$ of the nonetiolated cuttings formed roots $(P<$ 0.0001 ) (Fig. 2B).

In 2009 , etiolated cuttings had a mean of 11.3 roots per cutting as compared with 2.1 for nonetiolated cuttings (Fig. 3A). In every accession except USU-ACGR-1003, etiolated cuttings had significantly more roots than nonetiolated. Within etiolated accessions, the average number of roots per cutting ranged from 17.6 (USU-ACGR-1005) to 3.3 (USU-
ACGR-1003), with both USU-ACGR1005 and USU-ACGR-1004 having significantly more roots per cutting than the other three. There were no significant differences in the number of roots per cutting within the nonetiolated accessions. Overall, the number of roots on etiolated cuttings was significantly greater than the number of roots on nonetiolated cuttings $(P<$ $0.0001)$.

Similar trends were seen in 2010 with etiolated cuttings averaging 7.2 roots per cutting as compared with 0.5 for nonetiolated (Fig. 3B). Within accessions, all etiolated cuttings had significantly more roots per cutting than nonetiolated. Within etiolated cuttings, USU-ACGR-1004 had the highest average number of roots per cutting. Within nonetiolated accessions, only USU-ACGR-1004 had a mean of more than one root per cutting (1.1 roots). As in 2009 , etiolated cuttings had significantly more roots than nonetiolated $(P<0.0001)$.

Assessment of leaves at the time of sticking showed more damage to the leaves of etiolated than nonetiolated cuttings. In $2009,93 \%$ of the leaves of etiolated cuttings were damaged compared with $33 \%$ of the leaves on nonetiolated cuttings. Similarly, in $2010,90 \%$ of the leaves of etiolated cuttings were damaged while only $34 \%$ of the nonetiolated leaves were injured $(P<0.0001$ for each year, data not shown). A large number of leaves also senesced during the rooting period, with etiolated cuttings losing more leaves ( 1.35 leaves) than nonetiolated cuttings ( 0.68 leaf $)$ in 2009 (Fig. 4A). In 2010, the average number of leaves lost was 1.89 leaves per etiolated cutting and 0.98 leaf per nonetiolated cutting (Fig. 4B) $(P<0.0001$ for each year $)$.

Many of the etiolated and nonetiolated cuttings produced callus during the rooting process. In 2009 , $100 \%$ of the etiolated cuttings and $94 \%$ of the nonetiolated cuttings developed callus $(P=0.002)$ while in $2010,98 \%$ of the etiolated cuttings and $75 \%$ of the nonetiolated cuttings developed callus $(P<0.0001$, data not shown).

Etiolation causes a number of physiological responses including enhanced root initiation (Hartmann, et al., 2011), a decrease in chlorophyll content, and internode elongation (Salisbury and Ross, 1992). 


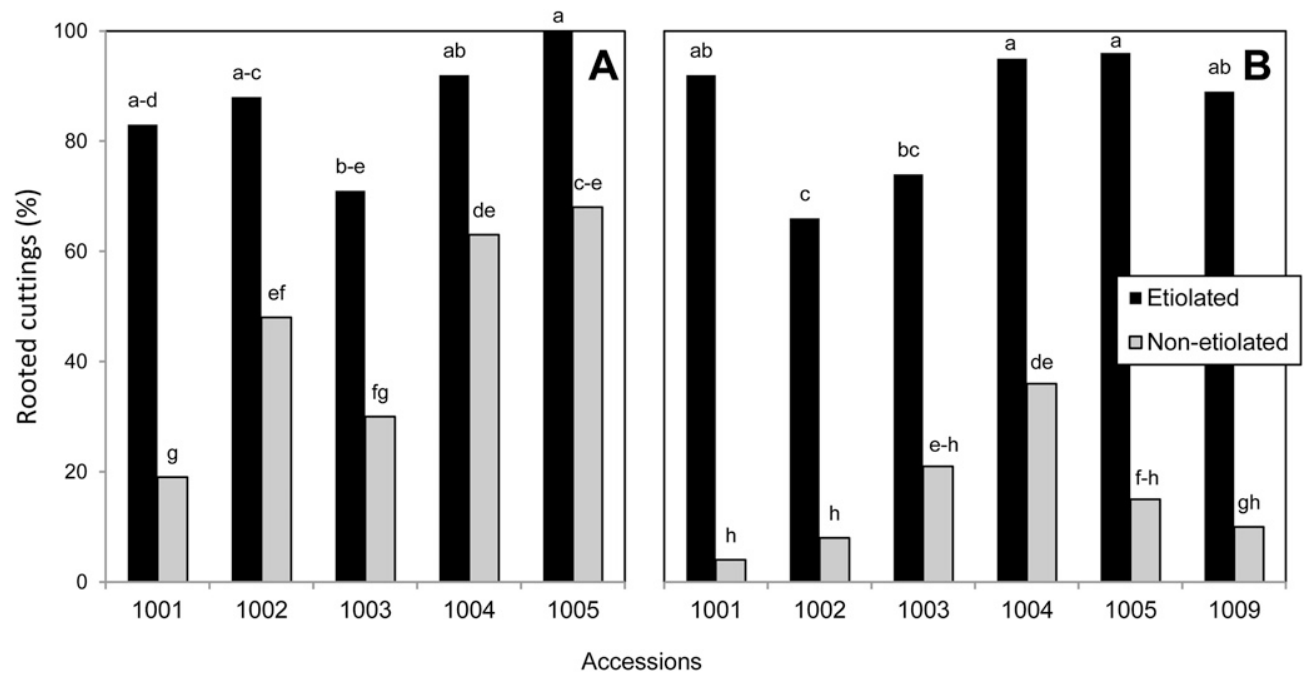

Fig. 2. The effect of etiolation on the percentage of rooted cuttings in bigtooth maple clones (USU-ACGR-1001, USUACGR-1002, USU-ACGR 1003, USU-ACGR-1004, USU-ACGR-1005, and USU-ACGR-1009) in (A) 2009 and (B) 2010. Etiolation significantly increased the percentage of rooted cuttings in all clones as shown by the two-sample $t$ test. Means with the same letter are not significantly different according to the SAS MIXED Procedure (SAS Institute, Cary, NC) at $P<0.001$.

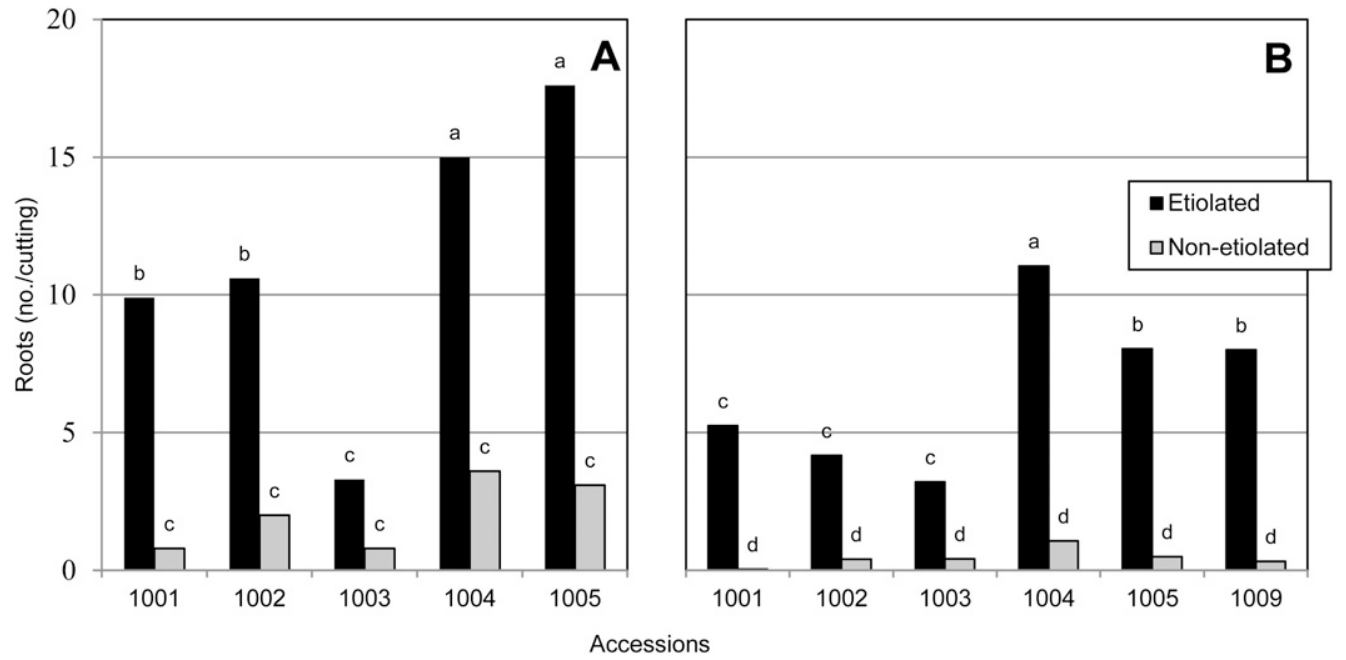

Fig. 3. The effect of etiolation on the average number of roots per cutting in bigtooth maple clones (USU-ACGR-1001, USUACGR-1002, USU-ACGR-1003, USU-ACGR-1004, USU-ACGR-1005, and USU-ACGR-1009) in (A) 2009 and (B) 2010. The number of roots on etiolated cuttings overall was significantly greater than the number of roots on nonetiolated cuttings $(P<0.0001)$. Means with the same letter are not significantly different according to the SAS MIXED Procedure (SAS Institute, Cary, NC).

The ability of the velour bag system to induce etiolation of new shoots was verified by two methods. First, a visual observation of stem color showed that in $2009,98 \%$ of the etiolated shoots were lighter in color than the nonetiolated. Shoot length averaged across all accessions and years was $27.2 \mathrm{~cm}$ for etiolated shoots and $18.8 \mathrm{~cm}$ for nonetiolated shoots $(P<$ 0.0001 , data not shown), which equates to a $45 \%$ increase in length of etiolated shoots. Cutting length was also greater with etiolation treatments $(14.1 \mathrm{~cm})$ than nonetiolated $(12.0 \mathrm{~cm})(P<0.0001$, data not shown).

\section{Discussion}

Black cloth shoot bags were an effective method for inducing etiolation and increasing rooting. This method increased rooting across accessions by $53 \%$ to $88 \%$ in 2010 , which compares very favorably to the work by Maynard and Bassuk (1988) where etiolation alone or with banding increased rooting of four cultivars of sugar maple by $0 \%$ to $44 \%$ over light grown controls. While the differences in rooting may be due to plant materials, local climates, and timing, these results suggest that the cloth bag method is a viable alternative to covering the entire plant with black cloth or plastic. 


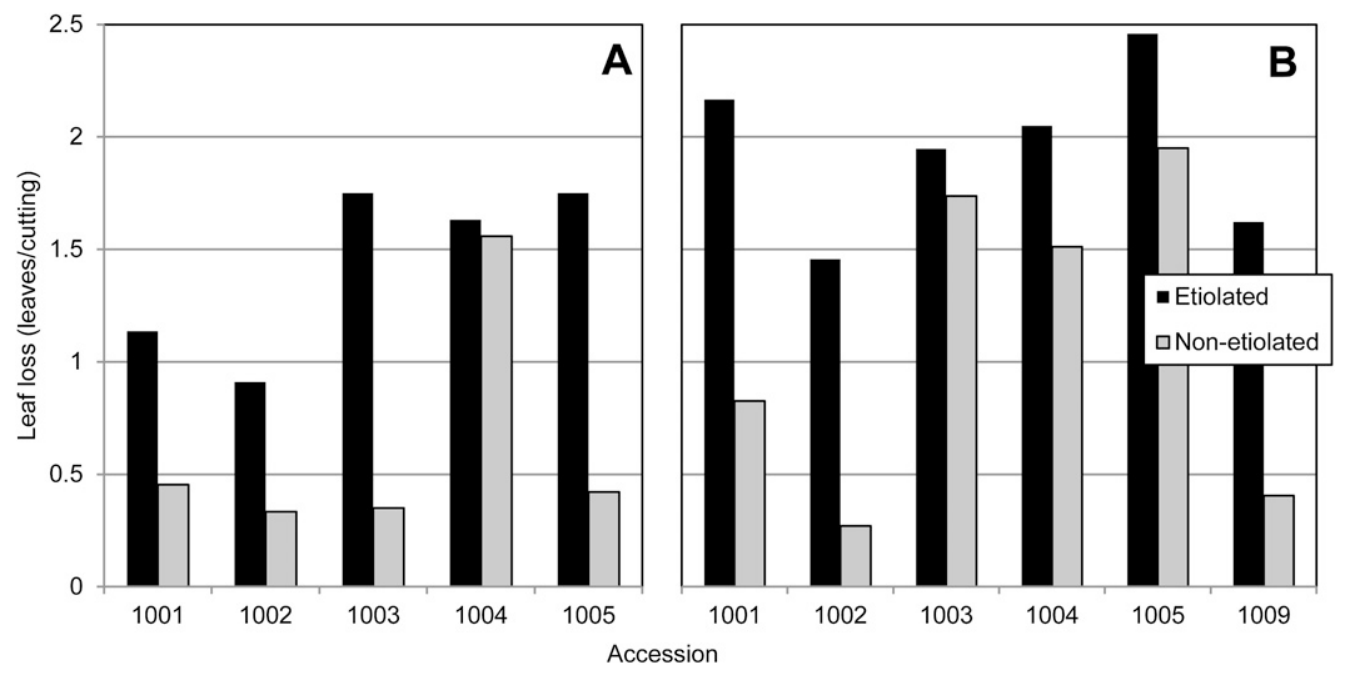

Fig. 4. The effect of etiolation on leaf loss after sticking cuttings of bigtooth maple clones (USU-ACGR-1001, USU-ACGR1002, USU-ACGR-1003, USU-ACGR-1004, USU-ACGR-1005, and USU-ACGR-1009) in (A) 2009 and (B) 2010.

Analysis of variance indicated that etiolated cuttings had a greater overall leaf loss than the nonetiolated cuttings for both years $(P<0.001)$.

It is of interest to note that cuttings in the nonetiolated controls also had higher rooting percentages than previously recorded with bigtooth maple. This response may be due to the combined effects of budding the accessions onto seedling rootstocks and heavily pruning them each year.

While etiolation through bagging is effective, it is not without its drawbacks. In both 2009 and 2010, the etiolation treatments resulted in leaf damage before the harvest of the shoots. We were unable to conclude from this research if the damage was a physiological response to etiolation or if the damage was due to the method of etiolation used (new shoots elongating through black, velour bags). Some damage appeared to be from heat, and a model system indicated that in full sun temperatures could rise at least $13{ }^{\circ} \mathrm{C}$ above ambient $\left(24^{\circ} \mathrm{C}\right)$ air temperature. Further damage was caused by paper wasps (Polistes metricus) nesting in the bags. We were unable to determine if leaf damage on bigtooth maple cuttings using bags for etiolation was a serious problem in successfully establishing bigtooth maple cuttings.

The data also showed that etiolated cuttings had an overall significantly greater leaf loss after the cuttings were struck than the nonetiolated cuttings. This leaf loss may have been due to natural physiological reasons, such as changes in light inducing leaf drop, or due to the damage caused by the bags. The increased leaf loss in 2010 may have been a response to cooler, wetter weather during shoot elongation in the field resulting in more impact of the bags on the leaves through wetting and temperature shifts.

The data does not explain the differences found in the percentage of rooted cuttings and number of roots per cutting from 2009 to 2010 . Undoubtedly the weather played a role in the different responses as the broad period of 20 Apr. to 7 June bracketing all bagging and cutting dates had 784 growing degree days [GDD (threshold temperature $40{ }^{\circ} \mathrm{F}$ )] in 2009 but only 516 for 2010 (Utah Climate Center, 2011). However, within the time frame of this research, there was no clear affect of GDD on rooting. GDD have been used to predict cutting dates for chinese pistache (Pistacia chinensis) (Dunn et al., 1996). They were also explored by Alsup et al. (2003) in relation to successful rooting of sugar maple, and while there was greater rooting early in the year and they were able to recommend taking cuttings at 350 to 520 GDD (threshold temperature $45^{\circ} \mathrm{F}$ ), they did not report a significant impact on root number or length. An additional factor in this research was that 2010 was a much wetter year with 6.5 inches of precipitation between 20 Apr. to 7 June as compared with 3.3 inches for the same period in 2009 (Utah Climate Center, 2011). A cooler, wetter spring may have resulted in cuttings that were less hardened off and therefore performed poorly under mist bench conditions.

It is not uncommon to find differences in rooting of maples because of cultivars (Wilkins et al., 1995). Such differences were also found in bigtooth maple. In both 2009 and 2010, etiolated USU-ACGR-1003 had the least percentage of rooted cuttings and roots per cutting. In contrast, USUACGR-1004 was either the first or second highest in rooting parameters. Given the past challenges in rooting bigtooth maple, perhaps part of the difficulty has been the germplasm selected for study.

Etiolation via black cloth bags appears to be a simple and effective means of increasing rooting of bigtooth maple cuttings. The commercial potential of this method is uncertain because of the concerns of leaf damage caused by side effects such as heat, physical restriction, and insect nesting. A possible solution to that concern would be to remove the bags when the cuttings are 10-12 cm long and cover the base of the stem with black hook and loop fastener or other opaque material (Maynard and Bassuk, 1987). This would require an extra step, but would allow the leaves to develop in a more natural environment and possibly reduce leaf damage and leaf loss during rooting. 


\section{Literature cited}

Alsup, C., J. Cole, and L. Claypool. 2003. Timing and IBA application affect rooting of Acer saccharum Marsh. stem tip cuttings. J. Prop. Ornamental Plants 3:42-46.

Barker, P.A. 1974. The spectacular canyon maple. Utah Sci. 35(1):7-10.

Bowen-O'Connor, C., J. Hubstenberger, C. Killough, D.M. VanLeeuwen, and R. St. Hilaire. 2007. In vitro propagation of Acer grandidentatum Nutt. In Vitro Cell. Dev. Biol. Plant 43:40-50.

Christensen, E.M. 1962. The root system of bigtooth maple. Great Basin Nat. 22:114-115.

Donnelly, J.R. and H.W. Yawney. 1972. Some factors associated with vegetatively propagating sugar maples by stem cuttings. Comb. Proc. Intl. Plant Prop. Soc. 22:413-430.

Dunn, D.E., J.C. Cole, and M.W. Smith. 1996. Timing of Pistacia chinensis Bunge. rooting using morphological markers associated with calendar date and degree days. J. Amer. Soc. Hort. Sci. 121:269273.
Eastmond, R.J. 1968. Vegetational changes in the mountain brush community of Utah during eighteen years. Brigham Young Univ., Provo, UT, MS Thesis.

Griffin, J. and N. Bassuk. 1996. Preliminary progress on the asexual propagation of oaks. Comb. Proc. Intl. Plant Prop. Soc. 46:487-494.

Hartmann, H.T., D.E. Kester, F.T. Davies, Jr., and R.L. Geneve. 2011. Hartmann and Kester's plant propagation: Principles and practices. 8th ed. Prentice Hall, Englewood Cliffs, NJ.

Herman, D.E. and C.E. Hess. 1963. The effect of etiolation upon the rooting of cuttings. Comb. Proc. Intl. Plant Prop. Soc. 13:42-62.

Kuhns, M. 2003. Canyon Maple: A Tree For the Interior West. 14 Jan. 2012. $<$ http://forestry.usu.edu/htm/cityand-town/tree-selection/canyon-maplea-tree-for-the-interior-west $>$.

Maynard, B.K. and N.L. Bassuk. 1987. Stock plant etiolation and blanching of woody plants prior to cutting propagation. J. Amer. Soc. Hort. Sci. 112:273276.
Maynard, B.K. and N.L. Bassuk. 1988. Etiolation to improve softwood cutting propagation: Aspects of hormone application and timing of taking cuttings. Comb. Proc. Intl. Plant. Prop. Soc. 37:420-427.

Salisbury, F.B. and C.W. Ross. 1992. Plant physiology. 4th ed. Wadsworth, Belmont, CA.

Satterthwaite, F.E. 1946. An approximate distribution of estimates of variance components. Biom. Bull. 2:110-114.

Tankersley, B.E., III. 1981. Growth and propagation of Acer grandidentatum Nutt. Texas A\&M Univ., College Station, MS Thesis.

Tankersley, B.E. and E.R. Emino. 1980. Acer grandidentatum: A potential new ornamental tree for the southwest. HortScience 15:274. (abstr.).

Utah Climate Center. 2011. GIS climate search COOP data. 14 Jan. 2012. <http:// climate.usurf.usu.edu/products/data.php>.

Wilkins, L.C., W.R. Graves, and A.M. Townsend. 1995. Development of plants from single-node cuttings differs among cultivars of red maple and Freeman maple. HortScience 30:360-362. 